\title{
Penetration and Establishment of Phakopsora pachyrhizi in Soybean Leaves as Observed by Transmission Electron Microscopy
}

\author{
H. H. Edwards and M. R. Bonde
}

First author: Western Illinois University, Department of Biological Sciences, 1 University Circle, Macomb 61455; and second author: United States Department of Agriculture-Agricultural Research Service, 1301 Ditto Ave., Fort Detrick, MD 21702. Accepted for publication 23 February 2011.

\section{ABSTRACT}

Edwards, H. H., and Bonde, M. R. 2011. Penetration and establishment of Phakopsora pachyrhizi in soybean leaves as observed by transmission electron microscopy. Phytopathology 101:894-900.

For over 30 years, it has been known that Phakopsora pachyrhizi is unusual in that it penetrates from urediniospores directly through the leaf cuticle without entering stomates. This unusual mode of penetration suggests that disease resistance mechanisms might exist for soybean rust that do not exist for most rust diseases. As a result, we decided to conduct a histological study using transmission electron microscopy to further elucidate the mechanisms of penetration and early establishment of $P$. pachyrhizi in soybean leaves. Based on our study, it was concluded that $P$. pachyrhizi utilizes primarily mechanical force, perhaps with the aid of digestive enzymes, to penetrate the cuticle on the leaf surface. However, the lack of deformation lines in micrographs indicated that digestive enzymes, without mechanical force, are used by the penetration hypha to penetrate the outer and inner epidermal cell walls. Digestive enzymes, again indicated by the lack of deformation lines, are used by haustorial mother cells to breach the walls of mesophyll cells to form haustoria. The possibility exists for eventual determination of the precise roles of pressure and digestive enzymes in the development of soybean rust and elucidation of some of the determinants of resistance and susceptibility to this important plant disease.
Soybean rust, caused by Phakopsora pachyrhizi Syd. \& P. Syd., was initially discovered in Japan in 1902 (12) and Australia in 1934, and adversely affects soybean production (5). Since then, it has become established throughout much of the world $(5,23)$. In 1994, the disease and pathogen were first detected in fields in Hawaii (18), and in central Africa in 1996 (21). In 2001, soybean rust appeared in Paraguay, the first documented case in the American continents (24), and subsequently spread through much of South America, inflicting heavy losses (29). Interest in the disease greatly increased in the United States in the fall of 2004, when infected soybean leaves were discovered in Louisiana (25).

P. pachyrhizi is believed to have been introduced into the United States from South America by urediniospores carried by hurricane Ivan in 2004 (25). Although urediniospores can survive for a few weeks, the fungus, being biotrophic, requires living cells for long-term survival. There is evidence that the pathogen has become established on other hosts, primarily kudzu (Pueraria montana (Lour.) Merr. var. lobata (Willd.) Sanjappa \& Pradeep) in some areas of the southern United States, where it is reported to survive year round (4). During the growing season, a favorable weather pattern potentially could spread the disease throughout the Midwest soybean-growing region, resulting in a significant

Corresponding author: Morris R. Bonde; E-mail address: Morris.Bonde@ars.usda.gov

The use of trade, firm, or corporation names in this publication is for the information and convenience of the reader. Such use does not constitute an official endorsement or approval by the United States Department of Agriculture or the Agricultural Research Service of any product or service to the exclusion of others that may be suitable. USDA is an equal opportunity provider and employer.

doi:10.1094/PHYTO-09-10-0248

This article is in the public domain and not copyrightable. It may be freely reprinted with customary crediting of the source. The American Phytopathological Society, 2011 economic impact. At present, only fungicides are available as a means of yield loss prevention. Considerable research has taken place to locate useful resistance genes and to develop rapid and effective diagnostic techniques (1,9). A detailed knowledge of how the fungus infects the host could be useful in directing research for effective controls based on disease resistance.

Biotrophic fungal pathogens use several different strategies to infect a host. Fungi, such as the apple scab pathogen, Venturia inaequalis (Cooke) G. Winter, penetrate directly through the epidermal cuticle and survive between the cuticle and epidermal cell wall, absorbing nutrients from the host epidermal cell (26). The cuticle consists of waxy and lipid materials that may be breached utilizing cutinases secreted by the fungal penetrating structure. Some biotrophic fungi penetrate directly through the cuticle and epidermal cell wall using mechanical force, as exhibited by the rice blast fungus Magnaporthe grisea (T. T. Herbert) M. E. Barr (13). Additional biotrophic fungi, such as the powdery mildews, directly penetrate through the cuticle and epidermal cell wall using cuticle-dissolving enzymes (cutinases) and cell-wall-digesting enzymes such as cellulases and hemicellulases (8). Other biotrophic fungi, including most rust pathogens, penetrate the host indirectly by first entering into the leaf mesophyll through stomata and then breaching the mesophyll cell wall (20). This latter mode of penetration does not require cutinases because there is no cuticle covering mesophyll cells. Consequently, the cell wall potentially could be penetrated by means of either mechanical forces or cell-wall-digesting enzymes.

$P$. pachyrhizi is one of only a few rust fungi that penetrate its host directly through the cuticle and epidermal cell wall, similar to the rice blast fungus and powdery mildews (3). Our research will demonstrate that $P$. pachyrhizi enters soybean leaves directly by penetration through the epidermal cuticle using mechanical force and, subsequently, through the epidermal cell wall by enzymatic digestion. Penetration through interior leaf walls also is by means of enzymatic digestion. 


\section{MATERIALS AND METHODS}

Plant host and pathogen isolate. Soybean 'Williams 82 ' was used throughout the study. Plants were grown one per $10.2-\mathrm{cm}-$ diameter clay pot, under lights, $16 \mathrm{~h}$ of day and $8 \mathrm{~h}$ of night, in the greenhouse using the standard greenhouse soil mix used at the Foreign Disease-Weed Science Research Unit containing a peatand compost-based mix $(60 \%)$, coarse perlite $(24 \%)$, coarse vermiculite (8\%), sand (8\%), 10-10-10 fertilizer, lime, trace minerals, and a wetting agent. $P$. pachyrhizi isolate AL 04-1, collected in Mobile County, AL in November 2004 and subsequently purified by several rounds of single-pustule inoculations, was used to inoculate the soybean plants. Spores were increased on Williams 82 plants, collected using a vacuum spore harvester (7), and periodically stored in a liquid nitrogen refrigerator at $-196^{\circ} \mathrm{C}$.

Inoculation and collection of leaves for transmission electron microscopy. One day prior to inoculation, urediniospores were removed from liquid nitrogen storage. They were heat shocked by submerging dry urediniospore aliquots, sealed in vials (Nunc CryoTube, Kamstrup, Denmark), into a $40^{\circ} \mathrm{C}$ water bath for $5 \mathrm{~min}$. Urediniospores then were hydrated by spreading them out on the bottom of an aluminum weigh boat and floating the boat on water in a closed plastic petri dish at room temperature $\left(\approx 21^{\circ} \mathrm{C}\right)$ for 16 or $24 \mathrm{~h}$. Following hydration, urediniospores were suspended in $0.02 \%$ (wt/wt) Tween 20 (Sigma-Aldrich, St. Louis), enumerated using a hemacytometer, and adjusted to1 $\times$ $10^{5}$ spores $/ \mathrm{ml}$. Four 30 -day-old Williams 82 plants at the three- to four-trifoliolate leaf stage were spray inoculated to runoff with the urediniospore suspension and placed in a dew chamber at $20^{\circ} \mathrm{C}$. Eight hours later, a second set of four pots of plants was inoculated as before and plants were placed in a dew chamber. One second (from the bottom) trifoliolate leaf and one third (from the bottom) trifoliolate leaf was collected at 3, 4, 5, 6, 8, and $16 \mathrm{~h}$ after inoculation. At $16 \mathrm{~h}$ after inoculation, two plants from the dew chamber were placed in a greenhouse and, at 2 and 3 weeks after inoculation, a second and third trifoliolate leaf were collected. The experiment was conducted in November 2005. In order to obtain further stages of pathogen development, in May 2007, a set of three additional plants were treated similarly as before. A second and third trifoliolate leaf were collected at 16, 22, and $24 \mathrm{~h}$ following inoculation.

Immediately following each leaf collection, leaves were placed abaxial side down on paper towels to remove excess moisture from their undersides, cut into $1-\mathrm{cm}^{2}$ pieces by means of a razor blade, and fixed for $3.5-8 \mathrm{~h}$ in $3 \%$ glutaraldehyde at room temperature $\left(\approx 21^{\circ} \mathrm{C}\right)$ in the light in $0.05 \mathrm{M}$ phosphate buffer. Following fixation, the glutaraldehyde buffer solution was removed, leaf pieces were rinsed several times with $0.05 \mathrm{M}$ phosphate buffer, and leaf pieces were refrigerated at $4{ }^{\circ} \mathrm{C}$ in the buffer until processed further.

Transmission electron microscopy. The glutaraldehyde-fixed pieces were cut into $1-\mathrm{mm}^{2}$ pieces and post-fixed in $2 \% \mathrm{OsO}_{4}$ in buffer for $2 \mathrm{~h}$. After rinsing in several changes of buffer, samples were dehydrated in an ethanol series and embedded in Spurr's resin (27). Thin sections were cut by means of a diamond knife on a Reichert OM2 ultramicrotome (Reichert Analytical Instruments, Depew, NY). In all, 20 to 25 serial sections were collected on a grid to ensure that most penetration sites would be contained on a few sequential grids. The sections were stained in $2 \%$ uranyl acetate $(\mathrm{pH} 5.0)$ and lead citrate $(\mathrm{pH} 12)$ and viewed with a Philips 201 transmission electron microscope (Philips, Eindhoven, The Netherlands).

\section{RESULTS}

Appressorial development. The appressorium generally formed over the anticlinal wall depression between adjacent epidermal cells (Fig. 1A). However, it was slightly offset because the penetration did not occur in the anticlinal area but in the outer epidermal wall near the cross wall (Figs. 1A and B and 2A to C).

A fibril-like matrix developed between the lower appressorial wall and the host epidermal cuticle (Fig. 1A). This matrix extended the entire length of the interface between the lower appressorium and the host cuticle (Fig. 1A).

The area on the lower side of the appressorium, where the penetration hypha forms, initially was identified by the presence of a dark-staining material (DSM) (Fig. 1B). The DSM appeared to have infused or replaced a portion of the lower appressorial wall and had arm-like extensions radiating into the appressorial protoplast. The extensions were limited by the invaginating plasma membrane; thus, the DSM was extracellular because it formed outside the appressorial protoplast.

The central portion of the DSM-infused appressorial wall disappeared, allowing the appressorial plasma membrane to bulge into the area vacated by the appressorial wall and make contact with the host cuticle (Fig. 2A). The DSM was present around the
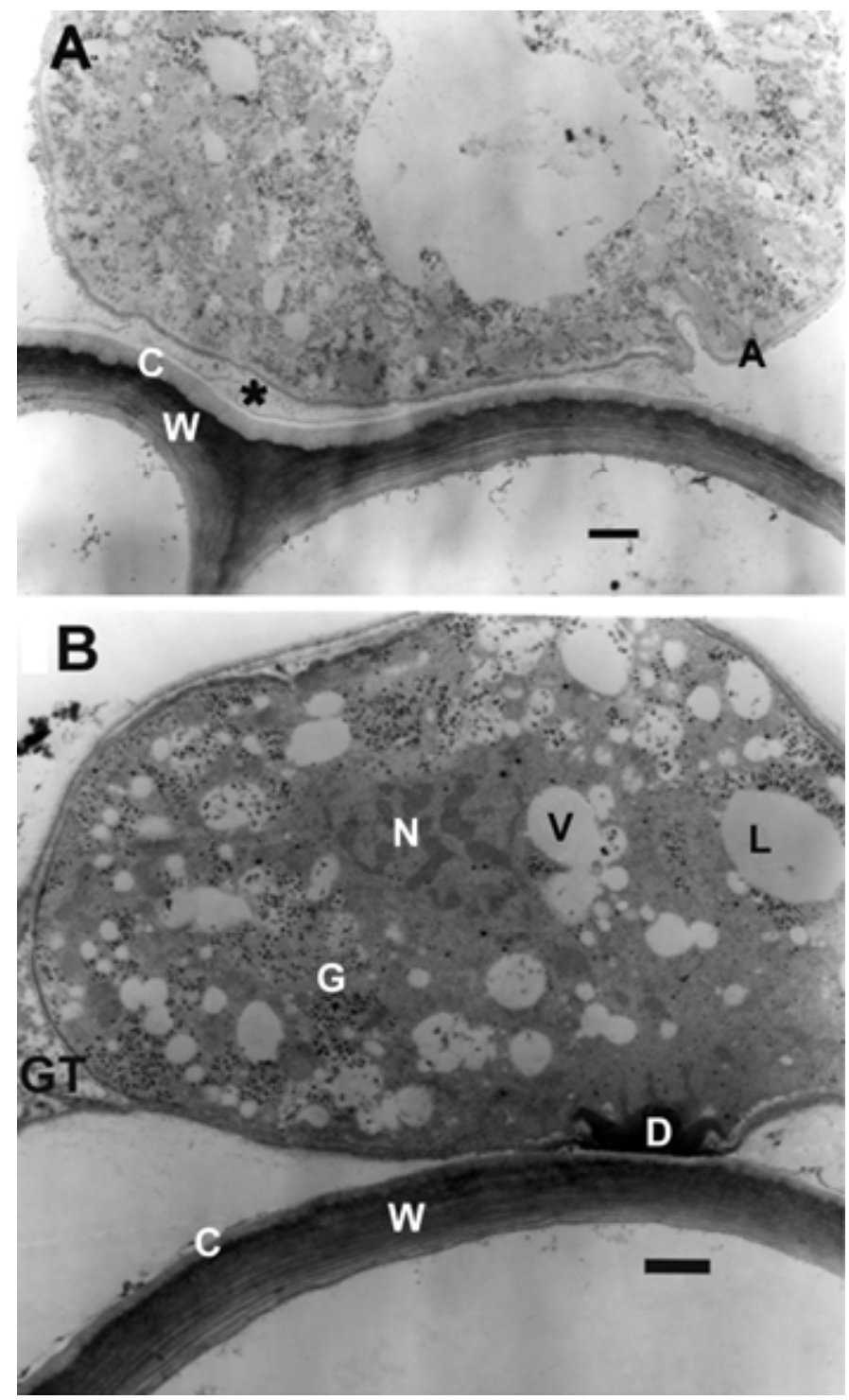

Fig. 1. Prepenetration of soybean leaf from appressorium. A, Formation of fibril-like matrix (*) between appressorial wall (A) and host cuticle (C) during early appressorial development. B, Formation of dark-staining material (D) in lower appressorial wall in the area where the penetration hypha will form. $\mathrm{A}=$ appressorial wall, $\mathrm{C}=$ host cuticle, $\mathrm{D}=$ dark-staining material, $\mathrm{G}=$ granules, $\mathrm{GT}=$ germ tube, $\mathrm{L}=$ lipid, $\mathrm{N}=$ nucleus, $\mathrm{V}=$ vacuole, $\mathrm{W}=$ host wall. Bars $=1 \mu \mathrm{m}$ ). 
edges of the bulge and extended into the developing appressorial cone and the appressorial cell wall around the bulge. The appressorial cone became highly branched and was surrounded by the invaginated plasma membrane. The appressorial cytoplasm immediately above the area where the plasma membrane made direct contact with the host cuticle (base of the appressorial cone) became devoid of any identifiable structures and developed a homogenous granular appearance (Fig. 2A and B).
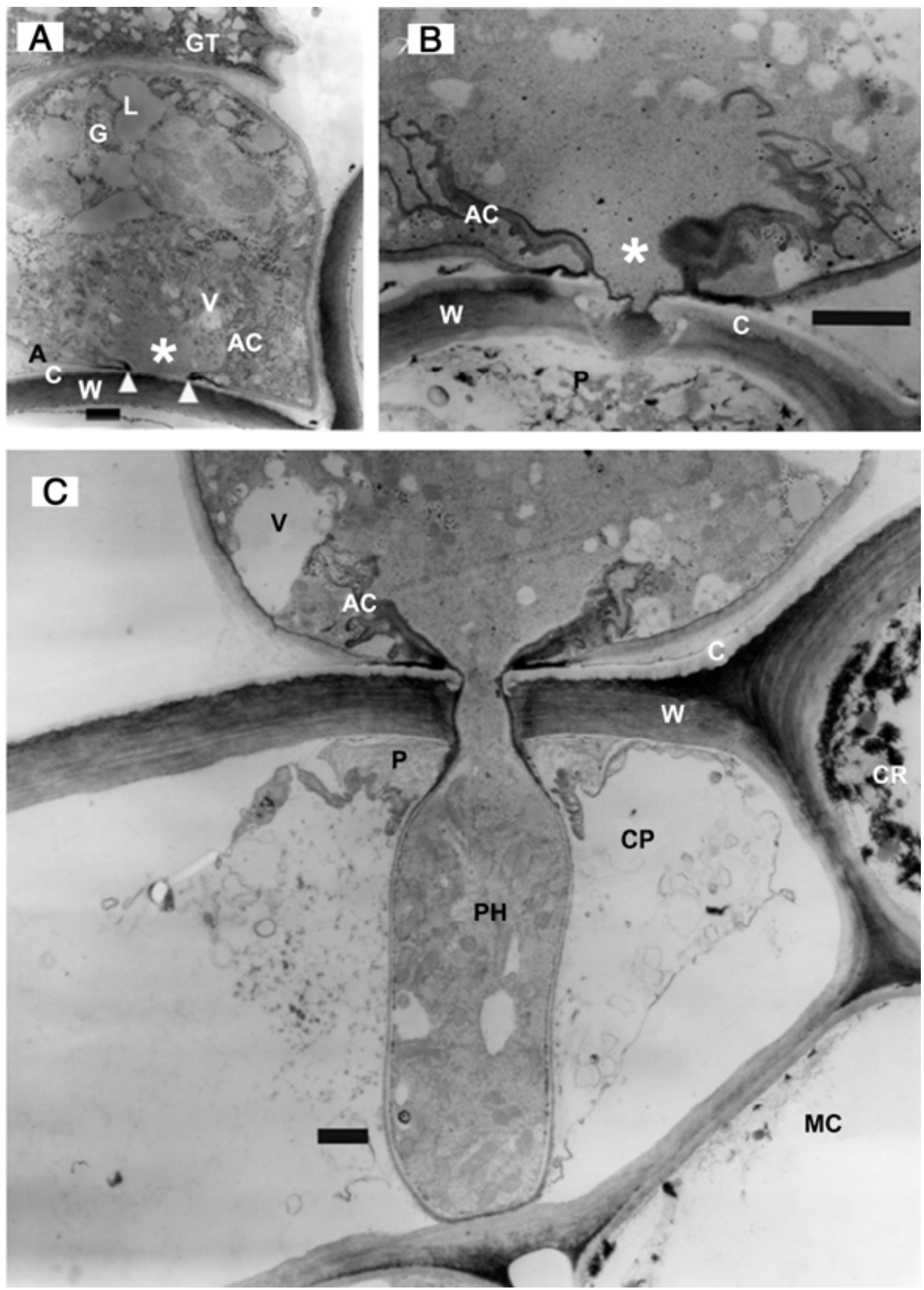

Fig. 2. Penetration of soybean leaf. A, Early stage in penetration of soybean outer epidermal cuticle. Asterisk shows where cuticle and wall penetration will occur. Appressorial wall is digested away and appressorial plasma membrane makes direct contact with host cuticle in the area between white triangles. B, Soybean epidermal cell cuticle and cell wall penetration. Asterisk shows nascent penetration hypha breaching the host cuticle and entering a cavity of digested host wall. C, Penetration hypha traversing soybean epidermal cell. Note infolded cuticle, indicating deflection by pressure, and lack of stress lines in epidermal wall, indicating digestion. $\mathrm{A}=$ appressorial wall, $\mathrm{AC}=$ appressorial cone, $\mathrm{C}=$ cuticle, $\mathrm{CP}=$ cytoplasm, $\mathrm{CR}=$ crystalline material, $\mathrm{G}=$ granules, $\mathrm{GT}=\mathrm{germ}$ tube, $\mathrm{L}=$ lipid, $\mathrm{MC}=$ mesophyll cell, $\mathrm{P}=$ papilla, $\mathrm{PH}=$ penetration hypha, $\mathrm{V}=$ vacuole, $\mathrm{W}=$ host wall. Bars $=1 \mu \mathrm{m}$. 
Penetration of host cuticle and cell wall. The penetration of the host cuticle and cell wall began with a central point of the plasma membrane bulge penetrating the host cuticle and pushing into the epidermal cell wall (Fig. 2B). However, at this stage, the host cell wall directly below the entering penetration hypha appeared to be a cavity devoid of cell wall components. Radiating from the penetrating point was a dark-staining substance filling the cavity (Fig. 2B). The substance had an appearance similar to
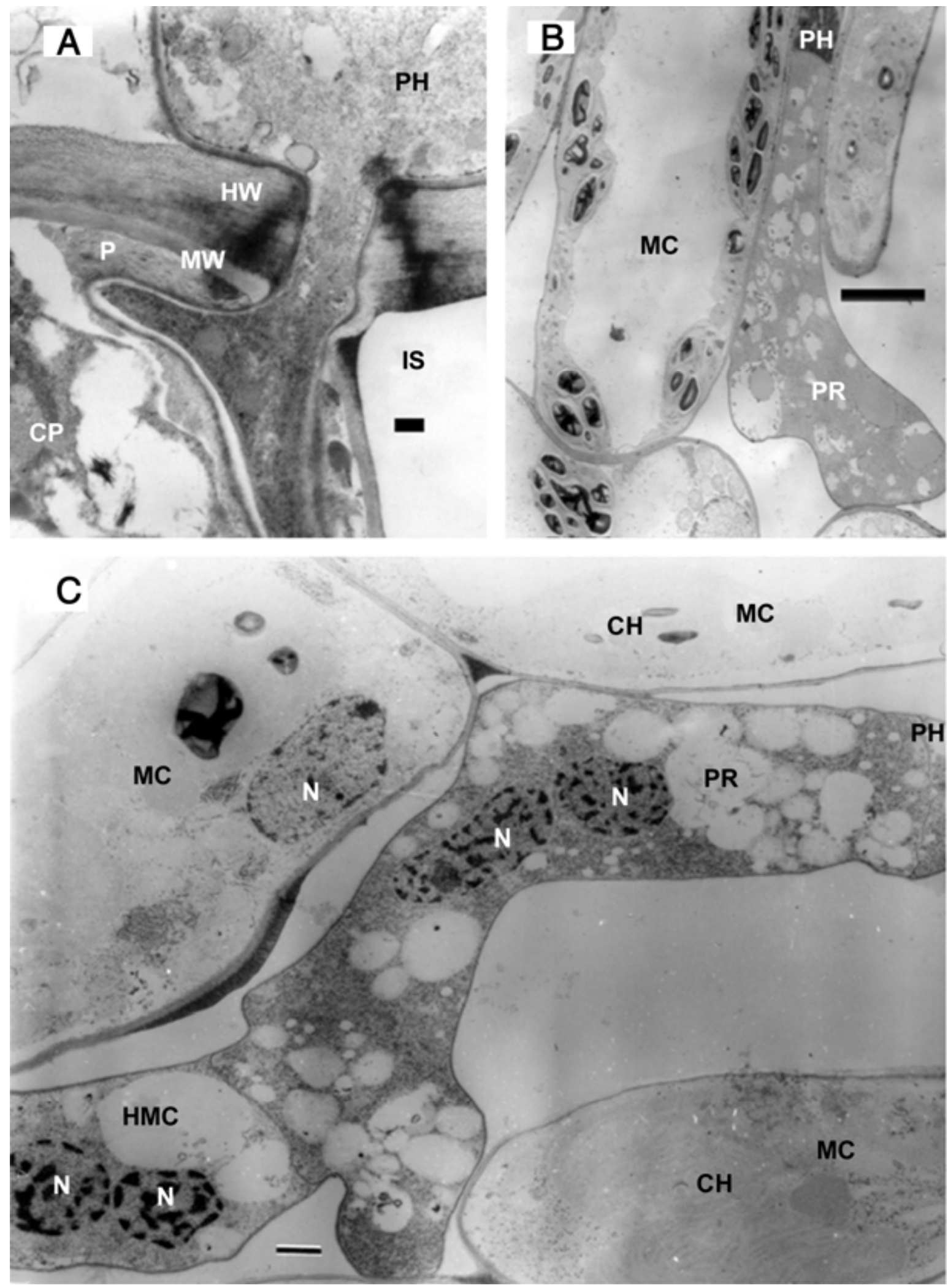

Fig. 3. Early colonization. A, Penetration hypha passing through lower soybean epidermal cell wall and adjacent mesophyll cell wall. Note lack of stress lines in both cell walls, indicating penetration by digestion. Bar $=0.5 \mu \mathrm{m}$. B, Penetration hypha and primary hypha growing between host mesophyll cells. Bar $=2 \mu \mathrm{m}$. $\mathbf{C}$, Penetration hypha, primary hypha, and haustorial mother cell developing among soybean mesophyll cells. Bar $=1 \mu \mathrm{m} . \mathrm{CH}=$ chloroplast, $\mathrm{CP}=$ cytoplasm, $\mathrm{HMC}=$ haustorial mother cell, HW = epidermal cell lower wall, $\mathrm{IS}=$ intercellular space, $\mathrm{MW}=$ mesophyll cell wall, $\mathrm{N}=$ nucleus, $\mathrm{P}=$ papilla, $\mathrm{PH}=$ penetration hypha, $\mathrm{PR}=$ primary hypha. 
the homogenous, granular material in the appressorial cone. The plasma membrane in the bulge became darker and thicker, as though it possessed a thin wall-like material to its outside (Fig. 2B), and possibly was the developing wall that eventually would cover the penetration hypha and was an extension of the extracellular wall-like material in the appressorial cone (Fig. 2C). The appressorial cytoplasm immediately above the penetration site inside the appressorial cone was still granular and devoid of
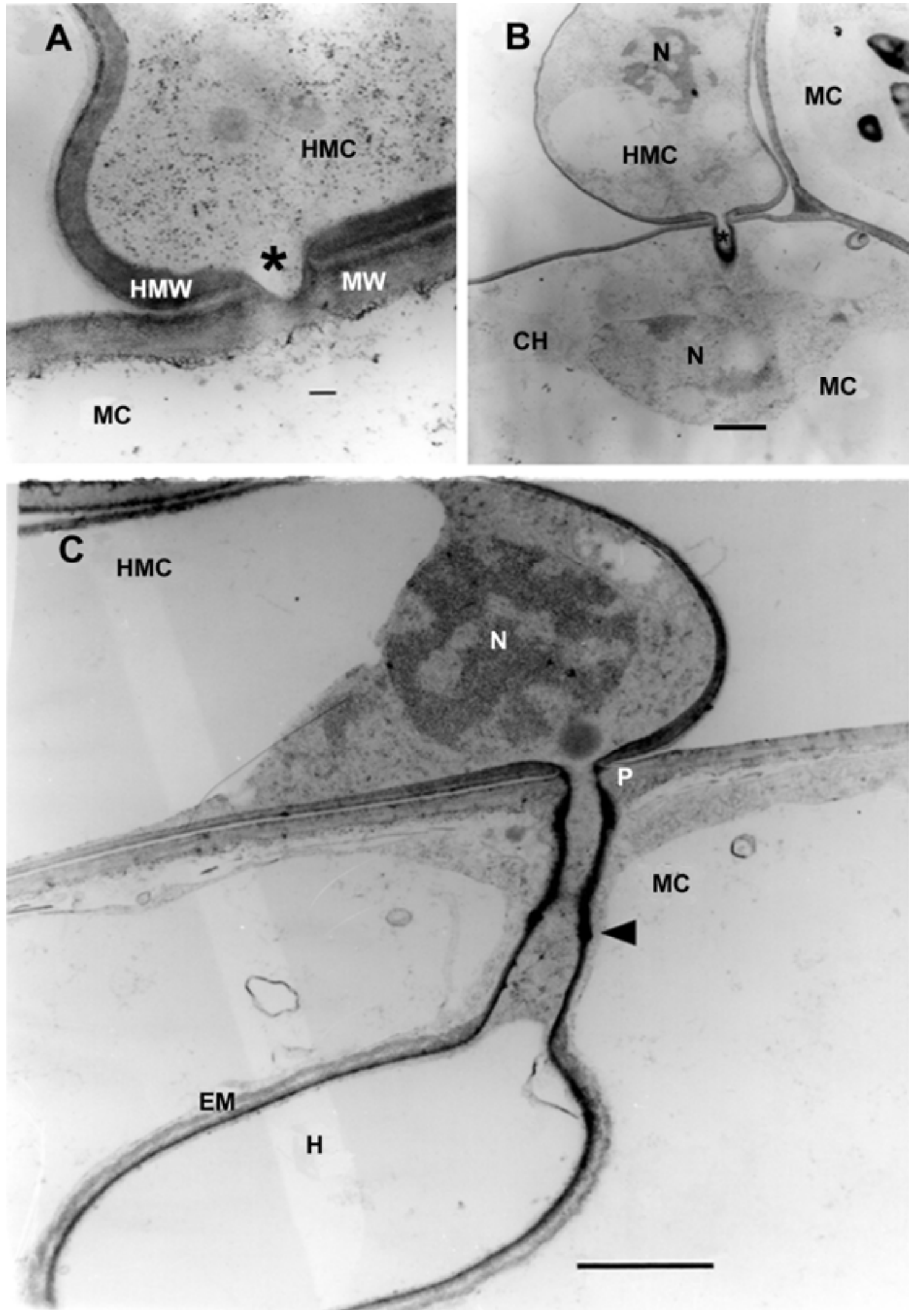

Fig. 4. Haustorial formation. A, Haustorial mother cell forming a nascent haustorial penetration peg. The peg (asterisk) has digested through the haustorial mother cell wall and partially through the mesophyll cell wall. B, Haustorial penetration peg (asterisk) developing into a soybean mesophyll cell. C, Haustorium in a soybean mesophyll cell. Triangle denotes the haustorial neck band. $\mathrm{C}=$ chloroplast, $\mathrm{EM}=$ extrahaustorial membrane, $\mathrm{H}=$ haustorium, $\mathrm{HMC}=$ haustorial mother cell, $\mathrm{HMW}=$ haustorial mother cell wall, $\mathrm{MC}=$ mesophyll cell, $\mathrm{MW}=$ mesophyll cell wall, $\mathrm{N}=$ nucleus, $\mathrm{P}=$ papilla. $\mathrm{Bars}=1 \mu \mathrm{m}$. 
cellular structures, suggesting that the penetration hypha either had digested the center of the host cuticle or used pressure to rupture the host cuticle. However, the host cell wall had mainly been digested, providing little resistance to the developing penetration hypha, as shown by lack of deformation lines in the penetrated host cell wall.

Penetration hypha formation. The penetration hypha formed as it passed through the penetration pore in the cuticle and outer epidermal cell wall (Fig. 2C). Subsequently, it expanded as it went through papillar material and traversed the host epidermal cell to reach the lower epidermal cell wall (Fig. 2C).

The penetration pore in the upper epidermal cell wall had the edge of the host cuticle pushed part way into the pore (Fig. 2C). However, there appeared to be little, if any, indication of deformation in the host cell wall, suggesting that the cell wall had been digested and that the penetration hypha had not pushed its way through (Fig. 2C). There was no indication of deformation in the lower epidermal cell wall at the site of penetration, which suggested that penetration was by enzymatic digestion (Fig. 3A). Commonly, but not always, once penetration occurred into a mesophyll cell, the penetration hypha grew along the inside of the wall between the protoplast and mesophyll cell wall (Fig. 3A).

Cross-sectional views revealed the formation of papillar material on the inside surface of penetrated mesophyll cells. However, the relationship between the penetration hypha and the host was difficult to discern because the host protoplast rapidly became disorganized following entry of the penetration hypha. In instances in which the penetration hypha did not enter a mesophyll cell but, instead, entered the intercellular space, no papilla formed. Soon after the penetration hypha entered an intercellular space, a cross wall formed in the penetration hypha, giving rise to a developing primary hypha (Fig. 3B).

Haustorial development. The primary hypha proceeded to grow between mesophyll cells (Fig. 3C). At some point, the primary hypha walled off a bleb-like haustorial mother cell (Fig. 3C). The haustorial mother cell subsequently appressed tightly to a host mesophyll cell (Fig. 4A). A small penetration peg formed and began digesting a hole through the mesophyll cell wall (Fig. 4A). The penetration peg invaginated into the mesophyll protoplast (Fig. 4B), pushing the mesophyll plasma membrane ahead of the peg. Eventually, the peg swelled into a haustorial lobe (Fig. 4C). Observation of the neck of the haustorium revealed the characteristic neck ring (Fig. 4C) found in other rust haustoria $(10,15)$.

Host epidermal cell changes during penetration. At early stages up to the breaching of the host cuticle, there were no visible host cytoplasmic responses (Figs. 1A and B and 2A). The host cytoplasm consisted of a thin layer which seemed to be easily separated from the host wall during fixation. When the cuticle was breached, the epidermal cell host cytoplasm responded with the formation of a papilla directly below the penetrated site (Fig. 2B and C). The papilla contained both lightand dark-staining components. After the penetration hypha entered an epidermal cell and grew to the bottom of the cell, the host cytoplasmic contents became considerably disorganized (Fig. 2C). Later, the host protoplast sometimes became filled with electron-dense crystalline material. This material also appeared in adjacent nonpenetrated epidermal cells and mesophyll cells, as well as in the penetration hypha after the primary hyphal cell was formed (Fig. 2C).

\section{DISCUSSION}

Although $P$. pachyrhizi is an economically important plant pathogen, there has been little work published on the penetration of the host material using the transmission electron microscope. The one major work (19) was published over 25 years ago and elucidated the entire developmental sequence from urediniospore production to the subsequent formation of urediniospores. Heath and Bonde (11) studied post-penetration development of the tropical rust of corn fungus Physopella zeae (Mains) Cummins \& Ramachar on Zea mays L., a fungus closely related to $P$. pachyrhizi, using transmission electron microscopy (TEM) but did not examine penetration of the leaf epidermis. Physopella zeae was reported by Bonde et al. (2) to penetrate the leaf epidermis directly through the cuticle and epidermal cell wall in a manner similar to P. pachyrhizi (3). Like P. pachyrhizi, Physopella zeae produced appressoria almost exclusively over anticlinal walls of the leaf epidermal cells (2).

The first visible interaction between the appressorium and the host was the formation of the fibril-like matrix occurring where the appressorium touched the cuticle (Fig. 1A). This is a commonly reported event occurring with most appressoriumcuticle interactions (13). The matrix is usually referred to as an "extracellular matrix" (ECM), and exposure to an alkaline bismuth staining procedure indicates the presence of polysaccharides (15). Hutchison et al. (14) detected the presence of glycoproteins in the ECM of Colletotrichum lindemuthianum (Sacc. \& Magnus) Briosi \& Cavara appressoria using TEM-immunogold labeling of proteins isolated from $C$. lindemuthianum material. One of these glycoproteins had characteristics suggesting adhesive properties. Thus, adhesion could be a major function of the fibril-like material observed in P. pachyrhizi appressoria. A lack of ability to adhere to the plant leaf surface perhaps plays a role in disease resistance to soybean rust.

The second visible change detected in the appressorium after matrix formation was the development of a DSM in the area of the appressorium where the penetration hypha eventually would form (Fig. 1B). Koch et al. (19) noted the electron-dense nature of the appressorial wall near the penetration hyphal opening. Their electron-dense area also extended into the appressorial cone. A similar DSM can be observed in Figure 2A in this study. There are many materials that will take up the uranium and osmium atoms rendering the area electron dense in TEM micrographs. Melanin or melanin-like substances would be good candidates for the DSM. Steiner and Oerke (28) recently reported the production of a melanized area (melanized appressorial ring structure [MARS]) in the lower appressorial wall of $V$. inaequalis comparable with the DSM occurring in Figure 2A. The presence of the MARS was observed to be required for pathogenicity. They speculated that the MARS might be required for the localization of digestive enzymes needed for fungal penetration of the cuticle. Melanization of appressoria has also been reported to be associated with the generation of high osmotic pressures in $M$. grisea and Colletotrichum spp. needed for pathogenicity $(6,13$, 14). Perhaps the DSM occurring in $P$. pachyrhizi appressoria is needed for enzyme localization, osmotic pressure development, or a combination of these processes.

A third visible change in the appressorium prior to penetration of the host cuticle and cell wall was the disappearance of the appressorial wall at the point-of-penetration hyphal formation (Fig. 2A). This resulted in the appressorial plasma membrane appressing directly on the host cuticle. To our knowledge, this feature has not previously been described; however, micrographs published in an article by Smereka et al. (26) appear to show a similar stage during penetration by $V$. inaequalis through the cuticle of apple leaves. This close proximity of the appressorial plasma membrane with the host cuticle may allow efficient transfer of cuticle or cell-wall-digesting enzymes to the host.

The penetration through the outer epidermal cuticle and cell wall by the penetration hypha of $P$. pachyrhizi appeared to be a two-stage process. Based on what can be observed in Figure 2B, the cuticle in the central area of the penetration pore was breached first. The breaching could have been by mechanical pressure or by localized digestion of the cuticle. This allowed a small tip of the penetration hypha to protrude into the cell wall below. The tip 
appeared to have secreted cell wall digestive enzymes because a cavity formed in the cell wall below the tip. The bulk of the penetration hypha could then push through the remainder of the cuticle, bending it downwards and through the cell wall cavity into the protoplast area. The bent-down cuticle was observed in later stages (Fig. 2C). It is observed that the host cell wall does not show any deformation in the cellulose microfibrils (Fig. 2C), indicating that little or no mechanical force was applied during this stage.

At the time the cuticle was breached by the penetration hypha, the host epidermal cytoplasm responded by formation of a papilla immediately below the penetration site. Papillae formation has been described in several fungal pathogen-host plant interactions, including Drechslera teres (Sacc.) Shoemaker on barley (Hordeum vulgare L.) (17), Puccinia striiformis f. sp. tritici Erikss. on wheat (22), and, recently, Phakopsora pachyrhizi on kudzu (Pueraria spp.) (16). With the latter, papillae were associated with the immune response (16).

The penetration hypha penetrated through the lower epidermal cell wall and sometimes through a mesophyll cell wall (Fig. 3A) without any microfibril deformations, again indicating that penetration was mediated by enzymatic digestion. In a similar manner, penetration by the penetration peg formed by the haustorial mother cell through the mesophyll cell wall also resulted in no microfibril deformations (Fig. 4A to C), indicating enzymatic digestion. Harder and Chong (10) made a similar observation in wheat rust haustorial formation.

Based on observations in this study, it was concluded that $P$. pachyrhizi utilizes mechanical force, perhaps with the aid of cuticle digesting enzymes, to penetrate the cuticle on the surface of the soybean leaf. Digestive enzymes are used by the penetration peg to penetrate the outer cell wall of the epidermal cell and inner epidermal and mesophyll cell walls within the leaf by the advancing hyphae. Apparently, digestive enzymes also are used to breach the mesophyll cell wall during haustorial development. The possibility exists for eventual determination of the precise roles of pressure and digestive enzymes in the development of soybean rust and elucidation of some of the determinants of resistance and susceptibility to this important plant disease.

\section{ACKNOWLEDGMENTS}

We thank S. Nester for her valuable technical assistance in the study.

\section{LITERATURE CITED}

1. Baysal-Gurel, F., Lewis Ivey, M. L., Dorrance, A., Luster, D., Frederick, R., Czarnecki, J., Boehm, M., and Miller, S. A. 2008. An immunofluorescence assay to detect urediniospores of Phakopsora pachyrhizi. Plant Dis. 92:1387-1393.

2. Bonde, M. R., Bromfield, K. R., and Melching, J. S. 1982. Morphological development of Physopella zeae on corn. Phytopathology 72:1489-1491.

3. Bonde, M. R., Melching, J. S., and Bromfield, K. R. 1976. Histology of the suscept- pathogen relationship between Glycine max and Phakopsora pachyrhizi, the cause of soybean rust. Phytopathology 66:1290-1294.

4. Bonde, M. R., Nester, S. E., Moore, W. F., and Allen, T. W. 2009. Comparative susceptibility of kudzu accessions from the southeastern United States to infection by Phakopsora pachyrhizi. Plant Dis. 93:593-598.

5. Bromfield, K. R. 1984. Soybean Rust. Monograph No. 11. American Phytopathological Society, St. Paul, MN.

6. Butler, M. J., Day, A. W., Henson, J. M, and Money, N. P. 2001. Pathogenic properties of fungal melanins. Mycologia 93:1-8.
7. Cherry, E., and Peet, C. E. 1966. An efficient device for the rapid collection of fungal spores from infected plants. Phytopathology 56:11021103.

8. Edwards, H. H., and Allen, P. J. 1970. A fine-structure study of primary infection process during infection of barley by Erysiphe graminis f. sp. hordei. Phytopathology 60:1504-1509.

9. Frederick, R. D., Snyder, C. L., Peterson, G. L., and Bonde, M. R. 2002. Polymerase chain reaction assays for the detection and discrimination of the soybean rust pathogens Phakopsora pachyrhizi and P. meibomiae. Phytopathology 92:217-227.

10. Harder, D. E., and Chong, J. 1984. Structure and physiology of haustoria. Pages 431-476 in: The Cereal Rusts, Vol. 1. W. R. Bushnell and A. P. Roelfs, eds. Academic Press, Orlando, FL.

11. Heath, M. C., and Bonde, M. R. 1983. Ultrastructural observations of the rust fungus Physopella zeae in Zea mays. Can. J. Bot. 61:2231-2242.

12. Henning, P. 1903. Some new Japanese Uredinales. IV. Hedwiga (Suppl.): 107-108.

13. Howard, R. J., and Valent, B. 1996. Breaking and entering: Host penetration by the fungal rice blast pathogen Magnaporthe grisea. Annu. Rev. Microbiol. 50:491-512.

14. Hutchison, D. A., Green, J. R., Wharton, P. S., and O'Connell, R. J. 2002. Identification and localization of glycoproteins in the extracellular matrices around germ-tubes and appressoria of Colletotrichum species. Mycol. Res. 106:729-736.

15. Jiang, S., Park, P., and Ishii, H. 2008. Ultrastructural study on acibenzolar-s methyl-induced scab resistance in epidermal pectin layers of Japanese pear leaves. Phytopathology 98:585-591.

16. Jordan, S. A., Mailhot, D. J., Gevens, A. J., Marois, J. J., Wright, D. L., Harmon, C. L., and Harmon, P. F. 2010. Characterization of kudzu (Pueraria spp.) resistance to Phakopsora pachyrhizi, the causal agent of soybean rust. Phytopathology 100:941-948.

17. Jorgensen, H. J. L., Lubeck, P. S., Thordal-Christensen, H., de Neergaard, E., and Smedegaard-Petersen, V. 1998. Mechanisms of induced resistance in barley against Drechslera teres. Phytopathology 88:698-707.

18. Killigore, E., and Heu, R. 1994. First report of soybean rust in Hawaii. Plant Dis. 78:1216.

19. Koch, E., Ebrahim-Nesbat, F., and Hoppe, H. H. 1983. Light and electron microscopic studies on the development of soybean rust (Phakopsora pachyrhizi Syd.) in susceptible soybean leaves. Phytopathol. Z. 106:302320 .

20. Leonard, K. J., and Szabo, L. J. 2005. Stem rust of small grains caused by Puccinia graminis. Mol. Plant Pathol. 6:99-111.

21. Levy, C. 2005. Epidemiology and control of soybean rust in southern Africa. Plant Dis. 89:669-674.

22. Liu, d., Xia, X.-C., He, Z.-H., and Xu, S.-C. 2008. A novel homeobox-like gene associated with reaction to stripe rust and powdery mildew in common wheat. Phytopathology 98:1291-1296.

23. Miles, M. R., Frederick, R. D., and Hartman, G. L. 2003. Soybean Rust: Is the U.S. Soybean Crop at Risk? APSnet feature. Online publication. American Phytopathological Society, St. Paul, MN.

24. Morel, W., and Yorinori, J. T. 2002. Situacion de la roja de la soja en el Paraguay. Bol de Diulgacion No. 44. Ministerio de Agricultura y Granaderia, Centro Regional de Investigacion Agricola, Capitan Miranda, Paraguay.

25. Schneider, R. W., Hollier, C. A., Whitam, H. K., Palm, M. E., Hernandez, J. R., Levy, L., and Devries-Paterson, R. 2005. First report of soybean rust caused by Phakopsora pachyrhizi in the continental United States. Plant Dis. 89:774.

26. Smereka, K. J., MacHardy, W. E., and Kausch, A. P. 1987. Cellular differentiation in Venturia inaequalis ascospores during germination and penetration of apple leaves. Can. J. Bot. 65:2549-2561.

27. Spurr, A. R. 1969. A low-viscosity epoxy resin embedding medium for electron microscopy. J. Ultrastruct. Res. 26:31-43.

28. Steiner, U., and Oerke, E.-C. 2007. Localized melanization of appressoria is required for pathogenicity of Venturia inaequalis. Phytopathology 97:1222-1230

29. Yorinori, J. T., Paiva, W. M., Frederick, R. D., Costamilan, L. M., Bertagnolli, P. F., Hartman, G. L., Goday, C. V., and Nunes, J. J. 2003. Epidemics of soybean rust (Phakopsora pachyrhizi) in Brazil and Paraguay from 2001 to 2003. Plant Dis. 89:675-677. 